\title{
HAMDAN BIN EL-MERHUM OSMAN AND THE OTTOMAN QUARANTINE REFORM
}

\section{INTRODUCTION}

The 1838 Ottoman quarantine reform was truly a turning point in the Empire's history of epidemic disease. One might gather that Sultan Mahmud II adopted the quarantine from western European advisers and physicians; as is evident from the recommendations presented to the Ottoman ruler with regard to implementation of the institution two years earlier by the Austrian doctor Anton Lago. ${ }^{1}$ Egyptian rival Muhammad Ali had launched his own quarantine under the guidance of foreign officials some seven years earlier. Mahmud II's predecessor Sultan Selim III had tried to do so in 1806. Many observers - Ottoman and Western - claimed that by 1840 the innovation had succeeded in eradicating plague permanently from the Empire. ${ }^{2}$

One seriously needs to address a number of issues in this account. Were the Ottomans and western Europeans, particularly the powerful British naval and commercial interests, unified in their support of the quarantine? One notices a number of Ottoman medical treatises in favour of this measure and a number of Anglo-American writers who were not. What exactly accounts for this discrepancy, and how did the geopolitical realities of the time, namely, the Ottoman push for reform and the concurrent British desire for commercial and colonial expansion, reflect this tension? Could one compare the Anglo-American critics' characterisation of the quarantine as a social disciplinary and ethnically divisive institution to Ottoman realities?

The following chapter will pursue these themes by discussing two interrelated sets of guiding questions. First, were Westerners or the Ottoman and other Muslim reformers primarily responsible for authoring and/or implementing 
quarantine and other contagionist public health policy reforms? How did such a question of control reflect upon the broader debate about nineteenth-century Ottoman reform as modernisation or Westernisation? Secondly, did quarantine and contagionist reforms lead to medical policing, where the state increasingly encroached upon civil society and individual liberty, as supposedly seen in the western European experience, or did it instead help to promote more popular participation in governmental affairs? Did such reform also promote ethnic divisions, as they were originally designed to build maritime nation-states, or could they be adopted to an alternative context, such as the multi-ethnic Ottoman Empire?

\section{WESTERNISATION VERSUS MODERNISATION}

One could easily be tempted to see the entire Muslim reform movement as an example of Westernisation, the wholesale adoption of modern European reforms, institutions and languages regardless of the socioeconomic and cultural context of the host country. Certainly, Westerners were often responsible for implementing quarantine and other contagionist institutions, such as the lazaretto and the bill of health system. It was no accident that the French armies that conquered Egypt in 1798 and Algeria in 1830 were the first to establish such measures in the Middle East. One might surmise that European diplomats and expatriate communities in the Ottoman Empire either directly introduced contagionist institutions or sent their recommendations indirectly to imperial officials, who copied them outright. Such actions could conceivably have led to a quarantine system throughout the Islamic world after 1830, which quickly eliminated plague as a result. Allegedly, Western know-how, which had conquered plague in London after 1665 and Marseilles in 1720, had finally extended beyond the continent. ${ }^{3}$

Yet a careful analysis of existing Ottoman sources supports the idea that Muslim reformers embraced quarantine and other modernising reforms in order to revitalise the state and to compete with their European neighbours. These modernisers adopted innovations, not simply by borrowing directly from Western ideas and institutions, but by the selective appropriation of new techniques within a local context. Ottoman, Egyptian and Tunisian reformers all pushed for quarantines and sought to have their own control. The long-term success of quarantine and other mercantilist measures was dependent on effective state formation. Quarantines were in fact mercantilist tools that protected and promoted internal economic development, and often flew in the face of free trade. Unfortunately, Ottoman dependence on Britain to ward off the Russian and Egyptian threat to imperial existence led in turn to sizable trade concessions 
to the British in the Balta Liman Treaty of 1838. These concessions would force the Ottomans to grant the British and other European powers partial supervision over the quarantines through the establishment of the Constantinople Superior Health Council. The European declaration of 'victory' over plague in the 1840s, and their dominance of the international sanitary conferences that followed in the ensuing decades, were reflective of this outside hegemony. ${ }^{4}$

Nevertheless, one needs to detail the arguments for Muslim quarantines as simply an altruistic, progressive Western idea. This is first evident in an analysis of native accounts of quarantine as an aspect of French colonisation of Egypt and Algeria, descriptions of the Europeans who introduced quarantine and lazarettos to the Ottoman Empire between 1807 and 1830, and the wholesale Ottoman adoption of the standard Western quarantine model by 1838 .

Admittedly, at least two native accounts of French colonisation readily identified quarantines with Western society. Al-Jabarti, a prominent Arab notable who was an eyewitness to Napoleon's invasion of Egypt in 1798, recalled that:

They [the French] exercise the greatest severity in the application of sanitary measures [which] harass the people and frighten them. When someone fell ill, the doctor visited him, and if he was recognised as stricken with plague, he was immediately transferred to quarantine without any of his family being able to see him afterwards ... If he recovered, he returned home; otherwise they had him buried, fully clothed ... His house remained closed for four days, and all his clothes were burned, ... If any passer-by was imprudent enough to touch the door of the house or to overstep the boundaries drawn around it, he was immediately arrested by the guards and sent to quarantine. Those individuals who undertook to wash the dead, to carry them or bury them, left their quarantine only to perform their functions. These measures ... induced many inhabitants to leave Cairo or to settle in the villages. ${ }^{5}$

Here Al-Jabarti describes the measures taken by the French in minute detail, but we do not get a real sense of whether he believed they were effective or not. What is most striking about this passage is instead Al-Jabarti's disillusionment with the inhumane and selfish treatment of the victims:

As for the French it is their custom not to bury their dead but to toss them on garbage heaps like the corpses of dogs and beasts, or to throw them into the sea. Among the other things which they said is that when someone becomes sick, they must inform the French who then send an authorised representative to examine him and to find out whether he has plague or not. They then decide what to do with him. ${ }^{6}$ 
While some historians have interpreted Al-Jabarti as someone who identified quarantine as totally alien to Islamic religious sensibilities - the beliefs that the faithful should not abandon those stricken with a horrible disease and that one should not take preventive measures against plague as it was the will of God - one should also not forget Al-Jabarti's own personal motives in writing his work. Al-Jabarti, who wrote his work in part to criticise Muhammad Ali's government as a conservative critic of reform, also thoroughly discussed French bureaucratic political reform ${ }^{7}$ - a hint that he might have actively participated in the short-lived Napoleonic government of Egypt in the wake of the 1798 invasion. Thus, it may well have been in his interest to distance himself from the most controversial aspects of the French occupation.

Hamdan Bin Osman Hoca, an Algerian who actively resisted the French shortly after they had occupied his country in 1830 , had a far more positive impression:

The measures the Europeans have implemented [in Algeria] against plague have helped them avoid plague [in Europe] for several hundred years. For example, they do not allow anyone from the countryside to enter a city unless they prove that they are not ill. The Europeans invented such quarantines in order to determine which people had the disease. ${ }^{8}$

Like Al-Jabarti, Hamdan credited the Europeans with the innovation: 'The quarantine first emerged in Europe and does not correspond to Islamic countries.' 9 However, he strongly believed that Muslims should also adopt the measure. Here he cited his own personal experience:

I myself took measures to prevent plague at home in Algeria. I did not leave my household and bought items that were carried by ship [from France], and not by land. I purchased no cloth or fabrics and avoided hiring maids from the provinces ... I would fumigate myself and not touch anyone, except when I had to go Friday prayers or funerals. Due to this, no one in my household was struck by plague. ${ }^{10}$

This passage shows Hamdan's own belief that the French quarantine did in fact save lives. Nonetheless, it is curious to note that the protectionist measures also included purchasing French cloth and fabrics and avoiding employing native Algerian maids. Hamdan, who wrote these passages in his own proposal for the Ottomans to implement plague, may have been aware of the mercantilist nature of this innovation. He likely saw such Western measures as a formula for ensuring a country's public health and commercial success. 
Early nineteenth-century critics of quarantines in the Ottoman Empire confirmed that the quarantine and other contagionist institutions, such as the lazaretto or pest house, were indeed Western ideas. Charles Maclean, a prolific British doctor, who actively lobbied for expanding the Levant Company's trade with the Ottoman Empire in 1817, wrote that the Ottoman sultan had toyed with the idea only after a European diplomat had proposed it to him:

Yet such was a measure seriously proposed, by the Austrian government to that of Turkey, in the reign of Selim [III (1789-1807)] with a view of extirpating epidemic diseases. That good, but in some respects weak, prince desirous of adopting every innovation, which he considered an improvement, however impractical, had himself no disinclination to entertain this proposition of the Austrian cabinet, which was formally presented to the Porte by the present worthy Internuncio Baron Stürmer. ${ }^{11}$

Furthermore, Maclean and James DeKay, an American who visited Istanbul in 1831-2 in the aftermath of the US trade agreement with the Ottoman Empire in May 1830 that guaranteed them most favoured nation trading status, also testified that western Europeans (also known as 'Franks') and local non-Muslims had established lazarettos of their own. Maclean complained extensively:

Concerning these infernal depositories ... miscalled pest hospitals in the Levant, it is proper that I should here say a few words. Their purpose is to serve as receptacles for all the miserable human beings, who are thought fit to objects of excommunication, by their families or employers, for having the misfortune to be attacked with the plague. They constitute the intermediate stage to the burying ground; to which these unfortunate victims of barbarity, are, after being almost always despoiled of their property, and often unfairly of their lives, generally in a few days duly transferred. These depots, constituting one of the most direful consequences of the doctrine of contagion, are of course only in use amongst the inhabitants of those persuasions, who entertain that pernicious belief: and their non-adoption by the Mohammedans is one of their circumstances, which contribute to except that branch of the Levant population, beyond their neighbors, from the ravages of pestilence ... None who enter them, indeed, are ever expected to return. $^{12}$

DeKay, like Maclean, viewed the lazaretto as a cynical plot to abandon the sick on the pretext that Western medical knowledge of the plague alone could save its victims: 
Leaving this scene, we passed under the walls of the plague hospital, built exclusively for Franks who may be affected with this disease. Over its melancholy walls we noticed the golden-berried ivy, the true ivy of the ancients, and this is the only locality about Constantinople in which I have seen it flourishing. The melancholy fate which has attended every patient admitted into this hospital gives some color to the reports which the Franks circulate of its character. According to their account, no patient has ever been known to leave this place alive, and the voi che entrate of Dante would seem to be the most appropriate inscription over its walls. ${ }^{13}$

One can confirm that certain Ottomans circles opposed quarantines and lazarettos, claiming that they were Western innovations that contradicted Muslim values. Osman Bin Süleyman Penah, the chief of Selim III's dockyards in Istanbul, the chief engineer and financial officer in charge of the Imperial Arsenal, was a most outspoken critic. Osman was personally opposed to the establishment of the Empire's first official lazaretto and medical school in the Arsenal in 1806, where Ottoman naval academy students were trained by European doctors in infectious diseases, surgery and anatomy. He in all likelihood wrote his 1804 tract against understanding plague as a contagious disease in full knowledge that the lazaretto would be established. Some three years after Osman wrote he would join Ataullah Şanizade, a former translator of Austrian medical texts, in engineering a coup against Selim III in reaction to the foreign presence and in the name of Islamic orthodoxy. ${ }^{14}$

Mahmud II took great care to include key Ottoman Muslim officials when he restarted contagionist reforms in the 1830s. Hamdan, recognised for his support of the Ottoman cause in Hac1 Ahmed's armed struggle in western Algeria and for a condemnation of colonial rule published in French, wrote his work on plague, this time in Ottoman Turkish, to counter any opposition from conservative religious quarters. Behçed Efendi, Mahmud II's chief physician, wrote a second published work in both Ottoman Turkish and French to explain that both cholera and plague were contagious diseases. At the same time, the Empire's chief religious official, the seyhül-islam, issued a fetva proclaiming that there was no 'harm to take refuge in God's favour from His wrath and attempt to take preventive measure when plague strikes'. ${ }^{15}$ These actions overcame conservative Muslim opposition to the 1838 quarantine despite the fact that Lago, and apparently some Viennese physicians, were also involved. Lago's work, a fortypage treatise on how modern the institutions and rules of modern quarantine and lazarettos could be implemented in the Empire, was apparently not widely distributed beyond the bureaucratic circles directly involved in the project. ${ }^{16}$

Finally, it is also evident that Hamdan, one of Mahmud II's chief advocates 
of quarantine and other contagionist reforms, based his proposal on western European standards. The European maritime quarantine system, based in large part on Venetian customs, had three outstanding features. Hamdan detailed the first, namely, bills of health 'given to ships leaving port', at the outset of his description of the European system:

Kings have their officials (balyos) all along the coast. They register every ship. Passengers have to provide sealed official papers indicating who they were, where they came from and certifying that there was no plague in their country. The officer is also in charge of describing where plague is. ${ }^{17}$

Hamdan followed up with an explanation of the second main feature, the European quarantine procedures:

There are five categories of quarantine. First, are those that came from nearby countries with a good quarantine. Sick passengers should be detained until they verify what type of disease/illness they have. Second, are those that came from remote countries with a good quarantine. They should be put in quarantine in case they interacted with other ships during the journey. Third, are those that came from non-plague-infested countries without a quarantine. They should be quarantined for twenty days. Fourth, are those that came from a plague-infested country but have no plague on board. Passengers should be kept in quarantine for two months. Fifth, and finally, are ships with plague. They should be expelled without hesitation. ${ }^{18}$

Hamdan also spoke to the European quarantine practice of isolating and purifying goods and personal effects:

If suspected, the passengers will go to the quarantine area but their belongings may be sunk or burnt. Passengers will be compensated accordingly. Guardsmen will be assigned to control the people under quarantine.

Processed raw materials like wool and cotton will be controlled carefully and put outside during the quarantine; materials that do not pass on the dangerous air, such as olive oil, will not be put under quarantine. ${ }^{19}$

Finally, Hamdan described the lazaretto, the third main feature:

Quarantine areas will be guarded on all sides; food will be provided for those who are under quarantine; private bathrooms will be provided ... People under quarantine will have rooms. Additional space will be provided if requested. 
People under quarantine can interact with each other irrespective of the time they spent under quarantine. If people become sick, their time under quarantine will increase..$^{20}$

Undoubtedly, the implementation of the Ottoman quarantine by 1838 - as seen in Hamdan's proposal - and Muhammad Ali's earlier 1812 regulations, were critical junctures in the history of medicine. ${ }^{21}$ The Europeans acted quickly after the Egyptians and Ottomans established quarantines to put some under international supervision, and, in the Ottoman case, many observers declared that the epidemic threat was 'eliminated' by the mid-1840s. One could easily conclude from these developments that quarantine was a progressive Western idea that eventually trickled down to the Ottomans and other Middle Eastern Muslim states. ${ }^{22}$

A number of questions complicate this scenario, leading to a fundamental re-evaluation of the Ottoman and other Muslim quarantine reforms as a form of Westernisation to a view that takes native agency far more into account. First, one must question, for instance, whether the quarantine reforms were purely 'Western' in origin.

Some Western travellers critical of the reform tended to portray the widely acclaimed Ottoman belief in anti-contagionism as a universal truth. DeKay disingenuously voiced this opinion in relation to cholera in 1833 on the eve of Mahmud II's quarantine reform, which was aimed in part at this disease:

Whether cholera be contagious is a question about which (whatever may be the fancies or the fears of ignorance) there is but one opinion among the Oriental physicians. They are unanimous in their belief of cholera being non-contagious; although partly to accommodate themselves to the vulgar prejudices and partly to inspire confidence, they direct fumigations and purifications by water. ${ }^{23}$

This statement is very odd given the fact that DeKay provided an accurate partial summary of a popular 1831 pamphlet on cholera by Behçed Efendi, published after the outbreak of cholera throughout the Empire that year. DeKay neglected to mention the section where Behçed directed the afflicted to take precautions:

The first thing to do is to avoid the place where the disease occurred. Do not approach the sick people, and do not talk with them because this disease is contagious like the plague! This has been tried and proven. If the disease occurs somewhere and someone dies or is ill, it is indispensable to immediately wash the garments of the sick and even the house furniture. ${ }^{24}$ 
There is similar, although indirect, evidence of a native inclination towards contagionist thought during the decades leading up to the 1838 reform. Maclean spoke at one point in 1817 about a case involving the Grand Vizier, the most powerful official in the Empire besides the sultan:

The present Grand Seignor is said to be one of those who entertains some apprehensions of this malady: and I have heard that, whilst I was in the hospital near the Seven Towers [in Istanbul], being struck with the death of his Hunkiar Imani, or Chaplain, he ordered the following maxim, extracted from the Hattisscherif, or collections of the sayings of Mohammed, preserved by tradition, to be brought to the recollection of the Mussulmaun people, from the principle mosques: 'The sick ought not to have communication from without, and he, who is well, ought to avoid meddling with the sick'. ${ }^{25}$

These sentiments for taking governmental action to prevent needless deaths were shared by Hamdan, one of the chief authors of the 1838 reform. He claimed that: 'Plague comes from putrid, fetid air which poisons light materials like cotton and wool [which people wear]. It then spreads to humans. ${ }^{26}$

One then wonders what Hamdan, Behçed and the Grand Vizier based their beliefs in plague and cholera's contagious nature upon? Arguably, all three were convinced, at least in part, by direct experience with the disease. One is tempted to further speculate that they were also informed by European notions of the disease, since Western medicine was also alleged to be determined by experience, an objectivity many prior historians of medicine believe to be absent from Muslim society. Yet even if European notions of contagionism affected any of the three cases, one should not forget that Muslim thinkers and statesmen often remained receptive to 'foreign' ideas as a general rule. Hamdan prominently mentioned the platitude: 'Wisdom is the believer's guide. He should take it from wherever he finds it.' For him, this truth was just as applicable to earlier times as it was in his day. He pointed out that just as the Arabs took much of their learning from the ancient Greeks, so too did the Europeans base their experimental knowledge on prior scholars. He jokingly chastised that the Turks should follow in the Europeans footsteps, since 'One should take knowledge, even if it comes from the Arabs. ${ }^{27}$

Nevertheless, Hamdan readily admitted European superiority in medicine and science because, to him, it was based upon experimental knowledge. In his eyes, the Ottomans should adopt quarantine, a practical application of this knowledge, and fundamentally rethink their approach towards learning new technology. Most controversially, Hamdan proclaimed that the Europeans' success was due to detaching natural philosophy (science and medicine) from religion. ${ }^{28}$ 
Here Hamdan had to convince a sceptical Muslim audience that adopting a secular approach was not a betrayal of the faith. Mahmud II, who apparently had not forgotten the opposition Selim III had faced from his own statesman Osman Bin Süleyman Penah, prefaced the publication of Hamdan's work with an official edict:

A tract, now in press, will clarify the nature and conditions of the disease [plague] and combat certain prejudices from religious zealots. To ignore the sovereign in this regard is to show ungratefulness ... Those who ignore [the tract] ... are subject to chastisement for their misdemeanour. ${ }^{29}$

Hamdan clarified that the 'religious zealots' to which Mahmud II referred had a 'vain imagination'. He alleged that, according to them:

The Europeans are infidels who have an irreligious, materialistic perspective. This fixed thinking harms the Muslim community by ignoring the source of detriment (plague) [and not adopting useful measures from Europe]. ${ }^{30}$

Hamdan followed up this statement in an extended argument on how earlier famed Islamic thinkers reinforced his views. He pointed out, for instance, that Ghazali, the great fourteenth-century Abbassid mystic believed that: 'One should not deny philosophy because it is distinct from religion. If we deny the philosophers, we only increase their evil attitude towards Islam. ${ }^{31}$ Hamdan also cited Ali bin Ebu Talib, a companion of the Prophet Muhammad, as justifying the need for Muslims to keep an open mind towards acquiring new knowledge from others:

If you know the truth, you know the people who tell the truth. Ignorance defeats humanity. If you do not know something, ask those who do. You are part of society and have a responsibility to it. ${ }^{32}$

Hamdan made a number of concessions in his proposal to accommodate religious sensibilities. He remarked at one point that imams should to be among the quarantine officials, since they needed 'to wash and prepare the dead'. He also mentioned that when he practised the quarantine in French-occupied Algeria, he did make sure to still attend Friday prayers and funerals. This was an acknowledgement that certain religious duties took precedence, even if it meant breaking some of the quarantine principles of personal isolation. To him, Ali's reminder of the Muslim duty to society, meaning the greater Islamic community, was a supreme virtue. ${ }^{33}$ This was a familiar argument to Ottoman Muslim elites, the 
majority of whom were adherents of the liberal Hanafi school of Sunni Islam. Ottoman reformers since Ebussuud Efendi, the sixteenth-century chief religious official, appealed to the maxim that innovations were justified if they saved their people. ${ }^{34}$

Hamdan's tract was not the first to attempt to sway the Ottoman ruling elite on the quarantine issue. Osman's earlier work condemning the institution had aimed at the same audience that ultimately deposed Selim III. Hamdan and Mahmud II might have referred to Osman as a 'religious zealot', but the fact was that he was among the privileged 'enlightened ulema' Selim III had entrusted with the reform movement. ${ }^{35}$ Thus, there was very little to distinguish Osman from Hamdan and other members of the Ottoman bureaucratic class except for the political and religious rhetoric which both of them used. Hence, terms like 'enlightened', 'zealot', 'backward' and 'dogmatic' were relative to the political struggles at the time at which they wrote.

What really counted towards both Osman's and Hamdan's success in persuading the Ottoman public was their shared sense of patriotism. Just as Osman was motivated by the large numbers of foreign doctors and other experts Selim III had employed to man his reform effort, so too Hamdan was convinced that the threat of European colonisation was very real. He illustrated this most clearly in his 1833 work, which protested to the French public how they had unfairly colonised Algeria:

One would think that an honourable nation [like the French] would not violate its own treaties so that we could enjoy liberty and be treated justly. It would not matter if Pierre or Paul governed, the principle of the French government was not to touch our religion. Religion is a moral thing that one should not dispute with us. The French people's fraternity will unite us with them. Civilisation is based on people's rights, and we are not scared of a civilised nation. Such were the reflections [before we found out differently] ... The Turks professed the same religion as us. We acknowledged their government, but our mores and religion were respected, our properties were not pillaged, our blood was not spilled, and our wives and children were not massacred. ${ }^{36}$

He also elaborated on the progressive nature of Ottoman rule: 'The Turks, "the so-called barbarians" maintained tolerance and effective rule in Algeria and elsewhere in the vicinity of Europe for three centuries. ${ }^{37}$

Such statements published in French and distributed in Paris just in time for a parliamentary debate on reconsidering Algerian policy reveal that Hamdan understood, and fully participated within, a Western political context. He, indeed, was using his knowledge of French political and literary culture to 
combat the French in the most effective way he knew. His daring protest, written in collaboration with Ottoman Foreign Minister Mustafa Reşid (1800-58), later the key architect of the Ottoman reform movement, resulted in Hamdan's permanent expulsion from Algeria after his work hit the press. The act must have also won him substantial gratitude among the Ottoman public, a reputation that Mahmud II was no doubt cognisant of when he backed his quarantine tract. The fact that Hamdan and the other quarantine reformers met no substantial opposition from 'religious zealots' highlighted the success of this strategy. ${ }^{38}$

This leads one to question whether the Ottoman quarantine was really in the European interests. Great Britain, by far the strongest commercial power in the eastern Mediterranean, as in much of the Indian and Atlantic oceans, had a growing engagement with the Ottoman economy. By the early nineteenth century, British merchants were eager to increase their sales of cotton goods and woollens in return for a variety of raw material products, including raw cotton and mohair. The Treaty of Balta Liman of 1838 - which greatly reduced external and internal tariffs to British traders - was a logical precondition for flooding the Ottoman market with British textiles.

One can see the dramatic upturn in the sale of both cotton goods and woollen textiles imported into the Ottoman Empire. ${ }^{39}$ The effect that this growth of imported cotton goods, from approximately 850,000 tons in 1838 to 3.8 million tons in 1855, and woollen textiles, from 38,000 tons to 135,000 tons, had on the Ottoman Empire was to inhibit domestic manufacturers. Urquhart described in detail his vision of this commercialisation of agriculture only some five years before the treaty:

The manufacture of cotton is the principal indoor occupation of the greater portion of the East - of the above sixty-millions of men, with whom our future commerce will probably be carried on through the scales of the Levant - of men who are applying their labour to manufacture the cotton, and wool, and silk, that clothe them, while their fields lie uncultivated under a climate producing all of those articles which at present give the highest remuneration for labour. Throughout these vast and varied regions, these resources have lain dormant, as in the Turkish village; because hitherto the first object of necessity was not furnished to them cheap enough to induce them to forgo its manufacture, and turned their attention to cultivation. How important, then, is it to establish the fact, that our cottons are at a sufficiently low price to induce them to forgo the home manufacturer! ... The village which was insulated before, now seeks to connect itself with the lines of communication with the principal marts; cultivation extends, wealth accumulates, instruction follows, desire for new objects increases, produce is raised, England's looms have called this prosperity into 
existence ... From the year 1827 to 1830 , our exports have increased from 531,704 to $1,139,613 .{ }^{40}$

All this trade would have been hindered by the new quarantine regulations, which targeted cotton and wool in particular. Thus, it is no surprise that authors like Maclean and Urquhart, both lobbyists for increasing trade with the Ottoman Empire, would condemn quarantines as a hindrance to trade and public health. As Chapter 3 demonstrated, quarantines were largely mercantilist measures aimed at promoting domestic industries at the expense of the free market. Hamdan, as we have noted previously, was well aware of quarantine's effects when he stated that the French colonists in Algeria purchased only goods imported from France, and that French quarantine officials charged all ships a fee in order to cover costs. ${ }^{41}$

Hamdan and his Ottoman compatriots were also likely aware of what the British inflicted upon some of their key trading partners. Since the 1750s the British East India Company had been instrumental in destroying India's cotton manufacturing and forcing its cotton growers to export the goods to London to help fuel textile industrial production. This led to increased British profits, an eventual motive for establishing outright colonial rule. ${ }^{42}$ In 1839 , just one year after the Balta Liman Treaty and the Ottoman quarantine reform, Great Britain went to war with China, provoked again by the British East India Company, which forced the ruling Qing dynasty to accept their illicit trade of opium despite its devastating social effects. This contradicted the ongoing colonialist myth that the British, like the other imperialist European powers, were civilising their new subjects.

Hamdan and others like him stressed the need for reform in view of such commercial imperialism. Hamdan, in fact, argued that Mahmud II pushed for an Ottoman quarantine to strengthen the state:

The Europeans overcame plague with their precautions and taught them to their progeny. As a result, their politics and trade developed. In contrast, Muslims wasted their people ... When he [Sultan Mahmud II] saw that another country was doing better than his, he hurried to amend the circumstances within the realm [by adopting the quarantine]. ${ }^{43}$

Likewise, Hamdan drew a parallel between quarantine and other key reforms, such as rearming the military:

Previously the Muslims waged war with spears, arrows and swords, while the Europeans invented gunpowder, rifles and cannons. When the Muslims acquired 
these materials from the Europeans, nobody protested but said it was necessary to acquire them. ${ }^{44}$

Of course, it would be a mistake to accept uncritically Hamdan's inference here that the Ottomans lagged far behind their European rivals from the seventeenth century onwards. Recent studies have shown that Ottoman gunpowder technology kept roughly apace. ${ }^{45}$ Hamdan's statement is also misleading if it referred to Mahmud II's reformed military. The sultan's abolition of the Janissary corps in 1826 was in fact a bloody slaughter of the capital's conservative opposition. His success in this endeavour paralleled the quarantine reform. Mahmud II, learning from the mistake Selim III made in allowing the janissaries to rally against his reform, this time cunningly plotted a coup to undermine his opposition. ${ }^{46}$

Nevertheless, Hamdan seemingly did imply that his reform, like earlier military reforms, would rely on foreign expertise, oddly enough from his old nemesis, the French: 'There is no harm in this, since [they] have training in the matter. ${ }^{47}$

This reliance on European methods and the French language can also be seen in 1838, when Mahmud II reorganised his military's medical school. Mahmud II clarified his long-term goal to assimilate European/French medical and scientific knowledge into an Ottoman Turkish cultural context in this excerpt from his inaugural address at the school:

I have given precedence to this school because it will be dedicated to a sacred duty - the preservation of human health ... The instruction in medicine will be in French. You may ask why this should be in a foreign language ... What we need is well-trained doctors for our troops and for our people, on the one hand, and to have the medical sciences incorporated into our own language and our own medical literature codified, on the other. Therefore, my purpose in having you study the French language is not to teach you French as such but that you may learn medicine - and in order to incorporate that science step-by-step into our own language. Medicine will be taught in Turkish in our land only when this has been done. ${ }^{48}$

It should be added that the medical school was under the direction of Abdülhak Molla, even though the majority of the staff were foreigners, largely French, Viennese and Italian. ${ }^{49}$

Hamdan also made it clear in his proposal that the quarantine was to remain under direct Ottoman supervision. In his opinion, it was necessary for the Sultan: 
To appoint a pious Muslim as the supervisor to implement a quarantine. That person should be mature, cognizant of the needs of the Islamic lands, and not prone to nepotism. He is charged with a duty to protect the Empire from plague. The supervisor will also convene a council regularly to implement and maintain the quarantine. They should meet every day to examine the newcomer's papers and decide how long subjects should stay in quarantine. The supervisor should have all necessary authority to carry out his mission to guard the Islamic land. ${ }^{50}$

Similarly, quarantine was only to be implemented in Istanbul, on both sides of the Straits, in order to better regulate international travel. As one would expect for border or customs officials, quarantine officers were expected to make an oath of loyalty to swear that they would not betray their cause. ${ }^{51}$

The fact that the British opposed Hamdan's proposal for direct Ottoman control over the quarantine should come as no surprise. Lord Ponsonby, the British Ambassador to the Porte at the time the proposal was formally discussed in March 1838, reflected the concerns of the British Board of Trade in a letter to Prime Minister Palmerston:

I must not omit to speak of the expenses to which the commercial Franks and others will be subjected by the quarantine; and that will not conceal my fear that, whatever measures may be adapted, the execution of them will be so bad as to subject us with all the many-fold inconveniences of sanitary regulations, without giving us the benefits that are generally supposed be derived from them ... I am fully impressed with the importance of this matter, and I shall be most happy to be assured of the probability of possibly extricating the plague from Constantinople. I am not assured of it - I doubt it extremely, and therefore I am adverse to these measures. ${ }^{52}$

The Board of Trade, acting upon such concerns of lost profit and enhanced Ottoman governmental control over international commerce, renewed its efforts for free trade. When the British drew up the Balta Liman Treaty in August 1838, they insisted that quarantine be supervised by the Constantinople Superior Health Council - a body that included representatives of all the major European powers. Mahmud II, under extreme pressure from the Russian Navy at that time, conceded to the British request. ${ }^{53}$

This frustrated tale of quarantine reform certainly belies the view that the western Europeans were responsible for implementing the institution in the Middle East, thereby eliminating plague by 1840. Admittedly, Hamdan and other Ottoman innovators, like Muhammad Ali in Egypt and Husayn Bey in Tunisia before him, did adopt the institution from western Europe. ${ }^{54}$ But they, like their 
mercantilist predecessors, sought to use quarantine as a tool to reinforce national sovereignty rather than tear it down. As Hamdan's case illustrates, he and other reformers were willing to use Western-inspired reforms, and their knowledge of the current European political and commercial context, to resist Western influence. This is a paradox that one can see throughout world history, such as when later Russian Marxists based their own modernisation and independence from the West on an ideology born in the West.

The final British protest of the quarantine was quite hypocritical, given the fact that they had used their own quarantine as an instrument of their own protectionist commercial policy but prevented the Ottomans from using the institution to stem a flood of British cotton and woollen textiles. Their declaration that two years of a weakly enforced quarantine in Istanbul had ended the nearly 500-year reign of the Ottoman Empire as 'the seminary of plague' seems simply too convenient a fit for British trading interests. ${ }^{55}$ One might reluctantly conclude that the disease was largely a socially constructed phenomena.

However, one must note that there was no mention in Hamdan's proposal of any domestic institution, in particular the quarantine of homes which Al-Jabarti was so horrified by when he witnessed the practice in occupied Egypt. Only Lago, the foreign doctor, recommended discriminatory practices against the poor as a risk group, but the reformists did not include his ideas ${ }^{56}$ The Ottomans might have allowed such practices among the European expatriates and the nonMuslim Greek, Armenian and Jewish communities, but there was little evidence of a systematic practice among the Muslims themselves.

\section{QUARANTINES AND ILLIBERALISM}

Edwin Ackerknecht's seminal 1948 essay 'Anti-Contagionism Between 1821 and 1867' argues that quarantines and contagionist thought often led to illiberalism and the police state - a thesis that infers that the 1838 Ottoman quarantine legislation may have reflected a similar tendency within the empire. ${ }^{57}$ One of Ackerknecht's main sources was the early nineteenth-century British writer Charles Maclean, who, besides writing extensively on his own investigations in Istanbul, adhered to a classical liberal argument that free trade and laissez-faire policies were essential to good governance. Maclean and others like him were opposed to quarantines and other welfare measures in general, claiming that their restrictions hurt human liberties, led to more arbitrary government and cost precious manpower and resources.

More recent literature on nineteenth-century medicine and government has largely seconded these arguments. Postmodernists like Michel Foucault and Bruno Latour saw nineteenth-century European medical reforms as encroaching 
upon individual autonomy and popular participation in governmental and social affairs. ${ }^{58}$ The doctors - and quarantine officials - were also potential liberals, members of the emerging commercial class who the state co-opted by including them in the reforms. If one sees this explanation of state-initiated reform in a non-continental European context, such as Mahmud II's efforts in the Ottoman Empire, it implies that the adoption of quarantine in 1838 would inhibit a 'progressive', 'liberal' path of state formation. Some might even view Mahmud II's and Hamdan's efforts at quarantine reform as setting the stage for autocracy, social discipline and, given the Empire's rich ethnic and religious diversity, even genocide. Ackerknecht's, Foucault's and Latour's focus on issues of policing and a crippled civil society in part reflected the impact of the Second World War and its legacy of illiberalism. Disillusionment with continental European civilisation would help to foster the neoliberal James C. Scott's claim that all state-initiated modernisation projects, regardless of geographic considerations, were doomed to failure. ${ }^{59}$

Yet, as Peter Baldwin has recently pointed out, such dichotomies and broad generalisations deserve extensive reconsideration. ${ }^{60}$ One might begin by remembering that Ackerknecht's nineteenth-century British liberals often wilfully obscured the mercantilist roots of their own society. As Chapter 3 has demonstrated, England's rise as an overseas commercial power rested upon seventeenth-century mercantilist reform, such as the Navigation Acts and quarantine legislation. These reforms - and the mercantilist discourse of both contagionist and anti-contagionist thought - helped to spawn the very dichotomised, ideologically charged arguments that Maclean and other nineteenth-century liberals made about their own society and how it compared with the Ottoman Empire. These writers' categorisation of the Ottomans as an anti-contagionist 'other' led them to dismiss out of hand the Ottoman attempts at modernisation - and quarantine reform.

Admittedly, Maclean and his fellow British liberals effectively illustrated that the English Quarantine Acts had had a policing aspect since the first years of their existence. By 1603, only seven years after London had initiated the Bills of Mortality, a law was passed which forbade members of infected households from leaving their habitations for six weeks. ${ }^{61}$ The houses were to have:

A large red cross, and Lord have mercy upon us on the door; and watchmen attending day and night to prevent anyone's going in and out, except physicians, surgeons, apothecaries, nurses, searchers, etc. allowed by authority: and this was to continue at least a month after all the family was dead or recovered. ${ }^{62}$

When Richard Mead authored the Quarantine Act of 1721, which regulated Levantine cotton and wool imports, he pushed for an extension of these disciplinary powers to quarantine entire city districts: 
But the greatest care must be taken that none pass without conforming themselves to this order, both by keeping diligent watch, and by punishing with the utmost severity, any that either have done so, or attempted it. And the better to discover such. It will be requisite to oblige all who travel in any part of the country, under the same penalties, to carry with them certificates, either of their coming from places not infected, or of their passing the line by permission. ${ }^{63}$

This call for 'internal passports' and emergency policing powers targeted the poor in particular, since, in his opinion, they were the most vulnerable and disorderly risk group:

All possible care ought still to be taken to remove whatever causes are found to breed and promote contagion. In order to do this, the overseers of the poor (who might be assisted herein, by other officers) should visit the dwellings of all the meaner sorts of inhabitants, and where they find them stifled up too close, and nasty, should lessen their number, by sending some into better lodgings, and should take care by all manner of provision and encouragement, to make them more cleanly and sweet ... When the sick families are gone, all the goods of the houses, in which they were, should be burned; nay the houses themselves, if that can conveniently be done. ${ }^{64}$

One may speculate that Mead reflected the common concern that London was growing too quickly for its own good even in 1720 - some sixty years before the dramatic increase in working-class immigration to the city was in full force during the Industrial Revolution. Imposing new regulations might keep this growth to a more reasonable level and assure the state and the more well-to-do that order would be maintained.

Later eighteenth-century advocates of quarantine reform, such as John Howard and Dr Patrick Russell, concurred that the poor were of special concern. Howard, for instance, mentioned that 'the air about poor patients is more infectious than about the rich'. ${ }^{65} \mathrm{He}$ later described his reasons:

The rich are less liable to the plague than the poor because they are more careful to avoid infection, and have larger and more airy apartments, and because they are more cleanly and live better on food, with plenty of vegetables. ${ }^{66}$

Russell largely agreed with Mead on the need to re-house the poor on grounds of the common good and public health: 
They perhaps might be lodged in barracks, or otherwise, in a way fully as comfortable as in their wretched dwellings in town, and, in case of a return of the plague, their being already in the country would save the police an infinite deal of trouble afterwards, as well as greatly facilitate attempts to extinguish the distemper, at its resuscitation in particular parishes. At any rate, it would be some check on the progress of contagion, the propagation of which is known to be much promoted by the intercourse of the lower class of the poor. ${ }^{67}$

Russell's commentary on barracks is especially important given the popularity of new British welfare legislation when he wrote his work in the 1760s. State 'drafts' of the poor into such housing, like the practice of indenturing, colonisation or impressment, were common practices in England during that time. ${ }^{68}$

Nevertheless, quarantine advocates like Mead and Russell understood that there were limits to policing powers during epidemics. Mead recognised, for instance, that an overly harsh policy towards the poor could alienate them:

The methods taken by the public, on such occasions, have always had the appearance of a severe discipline, and even punishment, rather than of compassionate care ... [They] must naturally make the infected conceal the disease as long as was possible. 69

Mead's opponents in the House of Lords came to a similar conclusion, arguing that they should quarantine only the sick, and opposed neighbourhood quarantines or resettling the poor away from affected areas:

Because such powers as these are utterly unknown to our constitution, and repugnant, we conceive, to the lenity of our mild and free government; a tender regard to which was shown by the act Jac. I, which took care only to confine infected persons within their own houses, and to support them under that confinement, and lodged the execution of such power solely in the civil magistrate. ${ }^{70}$

Despite these hesitations, quarantine opponents only took a categorical stand against policing and social discipline at the beginning of the nineteenth century. For instance, Maclean posited that even the earliest acts of isolating London's sick were inhumane and ineffective:

In 1665, the plague, in London, spread most rapidly, and proved most fatal, the very period that the shutting up of houses, supposed to be infected, and other restrictions upon intercourse, were most rigorously enforced: and it was after the 
houses were again laid open, and the people abandoned all other precautions, in despair, that the spreading of the disease, and its mortality, suddenly diminished, and ceased. ${ }^{71}$

Maclean also elaborated on how the eighteenth-century focus on the poor actually worsened England's social situation:

But the effects of this dread of contagion fall with ten-fold destruction upon the poor. They are not enabled to hold out, by present, or hopes of future reward, lures to meretricious attendance; and, as dread is generally more powerful than natural affection, they are not only almost certain of being left without attendance, but even without subsistence. If only suspected, they are deprived of employment: and if they have the good fortune to recover, they are still shunned as dangerous: so that the lot of those, whom an epidemic may have spared, is often beggary or starvation. ${ }^{72}$

The bottom line was that government-guided attempts to deal with the 'dangerous rabble' - stigmatised as an unwanted 'risk group' - created greater dependency on welfare measures and possibly planted the seeds of revolution. One might also infer, although Maclean does not mention it per se, the Malthusian argument that government spending on the poor was a waste, since they would perish anyway due to inadequate food supplies. ${ }^{73}$

Critics and advocates of quarantine were quick to tar their opponents with the brush of patriotism: contrasting societies in the debate was a constant thread. For example, many stressed the 'foreign' bureaucratic or illiberal aspects of quarantine. One can see anti-Catholic rhetoric when Mead's anonymous opponent claimed that quarantine advocates and officials worked 'under the power of the Pope and the ecclesiastical state', and that their beliefs were 'newly broached in arbitrary states and governments' ${ }^{74}$ Maclean similarly concluded that the chief opponent of his liberal arguments against quarantine was the Pope. ${ }^{75}$ Both these critics hoped to tap into the British antipathy towards Catholicism present since the Reformation. Others made the same connection to French mercantilists, who, of course, rivalled the British in the Levant trade throughout the eighteenth century. The House of Lords exposed this bias in 1721 when they criticised Mead's Quarantine Act:

These methods were copied from France, a kingdom whose pattern, in such cases, Great Britain should not follow; the government there being conducted by arbitrary power, and supported by standing armies. ${ }^{76}$ 
DeKay slightly tailored this line of argument when he went after governments who supported quarantines throughout the Mediterranean in 1831-2:

The rulers of Europe, who in all past times made quarantines the pretext for shutting out the contagion of liberal ideas, eagerly seized upon this disease as a reason for doubling their quarantines, and, if possible, increasing their rigor. This has been carried, during the present year, to such an extent, that all commercial intercourse was at a stand, and the short-sighted despots discovered at last that there were bounds and limits even to their arbitrary decrees. ${ }^{77}$

Here DeKay took aim at the rigorous controls many post-Napoleonic era European states put in place to prevent liberal opposition movements. He went on to castigate quarantine as a parasitical institution that hindered both commerce and the free flow of ideas:

It may safely be asserted that quarantines are jobs designedly intended to give salaries to physicians, superintendents, and guards, at the expense of the unfortunate sufferers. In the Levant, in addition to these powerful pecuniary reasons, others of a political nature tend to keep up the monstrous farce. During the thirtyor forty-days quarantine, ample time is allowed to procure all the information necessary respecting the opinions and views of the prisoner. He is surrounded by spies; and the men who supply him with food at twice its value pander to the guilty fears of his government, by furnishing them with the minutest chit-chat of the stranger, which may throw any light upon his political opinions. It is, in fact, not so much the contagion of disease as of liberal opinions that is dreaded, and in this view quarantines are to be despised as the instruments of despotism. ${ }^{78}$

The nineteenth-century liberals saw the Ottomans in a much more positive light.

Their idealisation of the 'Turks' as laudable anti-contagionists stretched from the sultan down to the man on the street. DeKay, indeed, viewed Sultan Mahmud II as the 'one crowned head who refused to establish quarantines, and contented himself with laughing at the beards of his royal brethren'. He praised him in 1831-2 for not going 'the whole length of what is considered in Europe as the index of civilization, to wit, custom houses and quarantines' ${ }^{79} \mathrm{He}$ argued that it was no surprise therefore, that:

The Turks content themselves with sending those attacked with plague to breathe the pure air of the country, and purified their dwellings. In the meantime they permit vessels to arrive from all parts of the world, and to depart, undisturbed 
and unimpeded by the delay, the expense, the imprisonment, and the official impertinence and extortion of a quarantine establishment. ${ }^{80}$

Even Maclean, who generally viewed the Ottoman rulers more negatively, favourably compared their government's abstention from policing 'domestic' quarantines to the history of such measures in his own country:

Under the Turkish dominion, however, each individual is left to act, according to his discretion, with respect to the government of himself, and of his family, in times of pestilence. He is not shut up in his house, surrounded by watchmen, shunned by his neighbours, or deserted by his children, if supposed to be infected. He may seek a more salubrious air, without the danger of perishing for want of food, or been driven back into a pestilential atmosphere by neighbouring peasants, both of which happened in the plague of London, in $1665 .{ }^{81}$

Such positive commentaries on the anti-contagionist Sultanate were matched by generalisations about the so-called popular Ottoman belief in anti-contagion. In DeKay's eyes, for example, the average Turk on the street did not heed constant rumours of plague:

I see the Turk marching along with an air of the greatest nonchalance, elbowing his way through the crowd as if unacquainted with the existence of such a disease as plague, or rather to show his constitutional fortitude and his utter contempt for the puerile precautions adopted by his timid neighbors; but then, on the other hand, everyone knows that Osman is an infidel, and of course not a civilized being, consequently he has not intellect enough to comprehend when he is in danger, and when he is safe. With this sapient conclusion, the Franks of Pera, who are far from being the representatives of the collective wisdom of Europe, persist in their childish terrors, and continue their absurd precautions. ${ }^{82}$

DeKay's satirical defence of the so-called 'fatalist Turk' as a 'noble savage' is matched by assertions that the 'Turk', in contrast to the contagionist European, helped those in need, regardless of the danger plague posed to his or her own well-being. The 'humane Turk' did not desert his or her friends or family when they had the misfortune to be struck by the plague. ${ }^{83}$

One cannot take such statements at face value. DeKay, writing in 1831-2, and Maclean, writing in 1817, were very likely both aware of the Ottoman Turks impending quarantine reforms, and a number of Turks, particularly bureaucratic elites if not the average Ottoman, suspected that plague was indeed a contagious disease. ${ }^{84}$ 
This critique especially holds true for DeKay's idealisation of the Ottoman Empire as a liberal republic. Ingratiating himself to Sultan Mahmud II he claimed that:

Like all his subjects, the Sultan is extremely temperate in eating, and his establishment is far from being on that expensive and magnificent scale which we are accustomed to attribute to Oriental courts. I have been assured by an officer of his household, that the expenses of his table rarely exceed ten piastres, or about fifty cents, a day; and from various anecdotes which I have elsewhere heard, I should not be disposed to believe that his annual expenses exceed those of the President of the United States. ${ }^{85}$

The modesty he mentioned of the sultan stems from Islam, a religion he believed empowered its adherents to constructively participate in political life:

Of the influence of Islamism on the actions and lives of its professors we have already treated, and it only remains to add that its direct tendency to counteract and mitigate the severity of the despotic governments, which in East have always found a congenial soil. It produces an equalizing effect, and is in fact a sort of religious republicanism, only extending much further than in our country [the United States] where a difference of complexion is fatal. It ennobles all who profess it, and furnishes an absolute title to any office short of the throne itself. ${ }^{86}$

Thus, he concluded that Muslim values were key to realising social and political inequalities. His comment here that Americans, who allegedly also tapped into the 'Protestant' mantra of 'an equality of all believers', could not overcome questions of racism (that is, a 'difference of complexion'). He also highlighted the Ottoman's 'perfect toleration' of other religious faiths in this regard. ${ }^{87}$

Perhaps even more important is DeKay's argument that Ottoman Muslim personal practice of giving to the poor obviated the need for state intervention:

The Turkish proverb, 'all that you give you will carry with you' beautifully expresses their belief in the importance and efficacy of alms. The giving of alms is frequently impressed as one of the highest duties of the believer; and we are told that at one time the practice was carried to such an extent as to produce a decree from the ulemah that not more than a fifth should be given to the poor. At present we are informed that is upon an average about two and a half percent. In no country in the world are beggars treated with more kindness and consideration than in Turkey, or their wants more speedily relieved. Poverty, in fact, appears to be a passport under which a beggar will not only thrust himself into the highest 
public offices, but even into the council chamber of the divan, with the certainty of having his wants relieved. ${ }^{88}$

This general sense of philanthropy thus explained why the Ottomans would not need or want a quarantine. They understood from the outset that the state had a sacred duty to protect the sick and poor.

The liberals, and Western commentators in general, did not spare differentiating the non-Muslim Ottoman minorities and European expatriates from the Turks. In particular, DeKay condemned the groups for their inhumane and irrational fear of plague:

When any ... [non-Muslim or European] is seized with it [plague], he is immediately abandoned to his fate. No medical man will dare approach him, on pain of being himself ruined; all rational mode of cure is neglected as useless, and the aid of medicine is given up in despair. That sympathy which our common nature yields to the sick is here denied. The [one] sick of the plague is put out of the pale of pity, and only looked upon as some noxious being, whom it ought be not only allowable, but meritorious, to destroy; and so the disease proceeds, rendering asunder the ties of families, extinguishing the common charities of life, eradicating the best feelings of our nature, till at length it has become one of the most dreadful moral as well as physical evils - at once the scourge and the scorn of humanity. ${ }^{89}$

This echoed Boccaccio's age-old criticism that the popular belief in contagionism led to the immoral abandonment of the stricken. ${ }^{90}$ DeKay then alluded to a personal case of plague involving his own next-door neighbour, Dr Visconti, who had dutifully attended many patients in the European dominated city quarters of Istanbul. When the 'fatal bubo' appeared near his bowels, no one would dare approach until they were offered the sizeable sum of 1,000 piastres. ${ }^{91}$

To DeKay, the non-Muslim mania about plague was a fact of life:

It is truly surprising that people who have been from their childhood accustomed to the presence of this disease should yet live in such continual terror. The first question asked is: 'Are there any new accidents today?' For by this polite periphrasis do the ignorant and timid European residents here designate one of the greatest scourges of humanity. I have noticed, for several days past, that people of all classes walk about the streets with smelling bottles in their hands, and with rags or bits of cotton thrust in their nostrils. To a newcomer it is laughable to witness the caution with which the Franks pick their way along the streets, carefully avoiding to tread on the least particle of woolen, cotton, or 
paper, and jumping from side to side to avoid touching even the clothes of the passers-by..$^{92}$

One should remember that there is no evidence in this or any other statement by Western travellers that the Levantine community ever was able to impose domestic quarantines by force. There are occasional hints by DeKay and Maclean that the 'municipal authorities', namely, the Greek Patriarch and the European consuls, called for quarantines, but the police were Ottoman Muslims who remained aloof. ${ }^{93}$

The writers also compare plague death rates among the communities. For instance, John Howard claimed that 'the Jews in Constantinople and Smyrna lose only one third ... the Turks lose two-thirds; other nations a little more or less' ${ }^{94}$ DeKay and Maclean came to similar conclusions about the higher rate for Turks and for Ottoman non-Muslims and Europeans.

The authors had a number of reasons for this difference. Howard pointed out that diet largely explained the discrepancy. The Turks had very meagre eating habits followed by the Ottoman Greeks and Jews:

The poorer sort of Greeks and Jews use much oil with their food; and this I reckon [is] a disadvantage to them. I have heard of instances of servants in European families, who through imprudence and carelessness, had been attacked with the plague, while the rest of the family have escaped it. ${ }^{95}$

DeKay also agreed that the plague rarely struck the "well-fed part of the population' ${ }^{96}$

However, DeKay also saw alcohol use as a major factor:

I was cautioned against dieting myself to ward off this disease, and indeed the use of spirits was warmly recommended. It is supposed that the rigid temperance of the Turks renders them more obnoxious to its attacks; but whether that be the case or not, it is certain that the Franks, who lived upon the fat of the land, and wash it down with copious draughts of wine, are rarely affected by this disease. ${ }^{97}$

DeKay characterised the Greeks as the most prolific drinkers. He noted that during his neighbour's funeral that the casket bearers, 'three Greeks, [took] the precautionary measure of getting most conspicuously drunk'.$^{98}$

This was not the only instance where the writers connected drug use to a different religious, ethnic or 'racial' group. The most popular drug use to disparage was opium, of course. Howard and Maclean alleged opium use to attack Turkish statesmen and physicians who disagreed with their arguments. On the one hand, 
Howard, who pushed the Ottomans to hire Western European doctors, claimed that their Turkish counterparts were dangerously incompetent:

The Turks have few hospitals at Constantinople. Those for the sick are a fort of caravansaries, in one of which, I saw many sick and dying objects lying on dirty mats on the floors. The surgeon seemed to be either extremely stupid, or intoxicated with opium. ${ }^{99}$

On the other hand, Maclean cursed the Ottoman government officials after they refused to hire him to conduct a study on plague:

It not only appears not to have been in the policy of the Ottoman Porte, to enter into my views of increasing the population of their territory; but, sensible of the opium, which could [also] not fail to attend the rejection of my propositions. ${ }^{100}$

DeKay, who was still hopeful of gaining Ottoman support for his own cause, tried to address this derision with his own anti-Semitic diatribe against the Ottoman Jewish minority:

It was here too that we saw for the first time an opium-eater. He was a miserablelooking Jew, pale and emaciated, and, although his eyes were rolling about every part of the room, he appeared to be unconscious of the presence of anyone around him. The idea of a Turk and an opium-eater is so naturally associated in our minds, that for a long period after our arrival here we were in daily expectation of meeting some Turk in the streets, maddened with opium, and ready to plunge with his yataghan into the body of the first Christian that crossed his path. It was not until after a residence of several months that we were enabled to put a just value upon the representation of those who deal in exaggeration, in order to make an impressive picture. As none fell in our way, we determined to ferret them out in their secret haunts, and even to experiment ourselves with this pleasing poison.

Opium is known to be one of the staple products of Turkey; and hence, it has been logically inferred, that everybody in the country must use it habitually. The Turks, by the same ingenious process of reasoning, conclude that the Americans are the most intolerable opium-eaters in the world, because they are the greatest purchasers of that commodity. ${ }^{101}$

DeKay expounded his anti-Semitism in another passage about the Ottoman Jews as a 'degraded race ... distinguished by its dirt and filth'. Oddly enough, DeKay also did not hesitate to use his fellow Americans as a foil for his idealisation of the Ottoman Turks. One may speculate that he was referring in part to his 'own' 
minority, the African-Americans. At one point in his text, he referred to two 'Blacks' who were the only ones to die from cholera during an outbreak in an American sloop-of-war sitting off Istanbul's Golden Horn. He explained they died because they refused to take modern medicine. ${ }^{102}$

The most striking aspect of the above liberal discourse on quarantines and social discipline is its superficial comparisons of the Anglo-American world to the foreign 'other'. While the writers described the 'domestic quarantine' in England, they did not refer at all to what policing measures were taken in 'despotic', 'contagionist' France and other continental European countries whose quarantines hurt their commerce. Similarly, the writers uniformly labelled the Ottomans as strictly 'anti-contagionist' during the reigns of Selim III and Mahmud II when quarantine reform was in the air. This mistake parallels misleading generalisations that Western observers made elsewhere, such as the claim that plague was endemic to the Middle East alone.

This illustrates the weakness of Ackerknecht's sources for the Ottoman Empire. Writers like Maclean and DeKay were committed first and foremost to an agenda of liberal free trade, and were more than willing to play with the facts accordingly. One could see this, for instance, in Maclean's vignette of the opium-smoking Turkish officials, and DeKay's glorification of Mahmud II and the chief court physician Behçed Efendi as strict anti-contagionists even when they knew the contrary was true. The truth according to these sources was relative - as the limited Ottoman sources we have on the subject point in an entirely different direction.

The question as to whether there were social consequences to the quarantine reforms is open to debate. Ottoman officials very occasionally mentioned poor migrants from the countryside as a potential cause of the plague. As early as 1792, an Ottoman imperial decree ordered that beggars in Istanbul who were sick with contagious diseases should be put into hospitals, while the able-bodied 'should be deported to their place of birth'. ${ }^{103}$ Such notions lingered even after Selim III was deposed by his so-called conservative opponents. An 1812 edict complained about recent poor migrants to Istanbul who spread plague by soliciting prostitutes: 'God's wrath has punished this behaviour by striking down the population with plague for the past three to five months. Get rid of the villainous households and the disease will stop ...' ${ }^{104}$ Hamdan chided the religious and sexual overtones, but accepted urban immigration as a cause when plague struck colonised Algeria:

The French hired [Algerian] maids to do shopping but would spread disease to their masters and sons after mixing with the local population in coffee houses, bath houses etc. ${ }^{105}$ 
Anton Lago also took up this issue in his treatise when he argued that the Ottomans should regard the poor as a risk group: quarantine officials should pay attention to the poor and the filthy environment in which they lived. He even recommended that the poor be isolated from those of better social standing when they were in the quarantines or lazarettos. ${ }^{106}$

The Ottomans were reluctant to embrace such principles within their reform efforts, however. Neither Hamdan nor any of the prominent Muslim quarantine officials seem to have promulgated discriminatory practices against the poor from 1838 until 1894, when the Europeans pushed the issue with regard to allegedly impoverished Muslim pilgrims from their colonial possessions who were seeking to visit Ottoman Mecca and Medina in order to perform their religious duties. Hamdan might have had his prejudices, but he and the other reformers were very aware that the Ottoman religious authorities - the traditional overseers of the urban poor - might be very leery of sanitary policing practices that would undermine their authority.

In contrast, it was the Europeans who stressed the so-called social and ethnic aspects of the Ottoman quarantine. Lord Ponsonby, the British Ambassador to Istanbul who derailed the 1838 quarantine, protested Sultan Mahmud II's alleged consideration of a domestic quarantine:

The other proposal is to empower the health officials to enter any house in which they may believe the plague to have broken out and to take such measures as they may judge expedient, being authorised to act by some member of the Board of Health. This power will occasion a serious inroad upon one great and precious principle and right created by our capitulations, that is the inviolability of the domicile of the Frank; and it will probably occasion robbery, perhaps murders, and certainly infinite distress and misery to the sick. ${ }^{107}$

This statement strikes a familiar chord: the Ottomans, like other quarantinists, were arbitrary, despotic and could not be trusted with control. The 'Franks', namely, European expatriates and Istanbul's and Smyrna's Greek minority, were able to run hospitals of their own. There were occasional contests between the hospital authorities, who wished to extend their own influence to nearby Muslim residents, and the central authorities, who occasionally sent guardsmen to extract fees for new construction and collecting taxes. ${ }^{108}$ Thus, it was the Europeans, and not the Ottomans, who insisted that a domestic quarantine would define the superiority of one religious community over another.

In a similar vein, I have not been able to locate any case of anti-Semitism in the source material except for Hamdan's protest to the French for occupying Algeria. His derogatory comments about Algeria's Jews as 'money 
grubbing' and 'exploitative' can be traced to the French use of ethnic politics to consolidate its rule. ${ }^{109}$ One sees here a foretaste of twentieth-century Palestinian anti-Semitism, which was based on a similar resentment of outside intervention.

Liberal writers, like Maclean and DeKay, themselves contributed to the cause of Western imperialist expansion in the Middle East by highlighting ethnic, religious and class differences within the Empire. Their success in convincing their English-speaking readers to support overseas commercial efforts helped to bring greater instability. The breakdown of the Ottoman protectionist measures, and Grand Vizier Mustafa Reşid Pasha's declaration of the equality of all Ottomans, regardless of religious creed, encouraged both Christian minority separatist movements (that is, Greeks, Armenians, Marionites) and their European sponsors to take advantage of imperial weakness. ${ }^{110}$ This sense of vulnerability, very similar to what Hamdan felt about the French occupation of Algeria, would be the true harbinger of ethnic nationalism in the century to come. In sum, it was the imperialist powers, and not the Ottoman drive towards modernisation and quarantine reform, that promoted illiberal notions of identity and governance.

\section{CONCLUSION}

The 1838 Ottoman quarantine lends important new insights into the Empire's reform movement. Native reformers like Sultan Mahmud II and Hamdan initiated the measure to strengthen the Ottoman state and to resist British commercial expansion rather than pave the way for it. Here paradoxically the Ottoman reformists followed the same path trodden by the English some two centuries earlier. The quarantine and contagionist reforms, like modernisation as a whole, may have strived to order society and increase the financial reach of the state. However, they were not bound to stress ethnic and religious differences through policing measures with the teleological aim of separatist nationalism. It was, ironically, the early nineteenth-century Anglo-American treatise writers who spoke of human and economic liberty who were the ones to encourage ethnic, religious and even racial division instead of a reinvigorated, sovereign and self-sufficient Ottoman government. Equally ironically, the Ottoman reformers who succeeded in convincing their domestic critics of the need to resist outside powers caved in to British pressure to establish the Constantinople Superior Health Council. If one could have asked Hamdan after 1840 if he agreed that the plague was gone, he might have quipped that the only 'sick' patient was the Ottoman state itself. 


\section{NOTES}

1. Lago, Risale-i Karantina.

2. Berkes, Development of Secularism in Turkey, p. 121; Panzac, La Peste dans l'Empire Ottoman, pp. 475-83.

3. Kuhnke, Lives at Risk, pp. 3-4, 9-10; Panzac, La Peste dans l'Empire Ottoman, pp. 11-16.

4. Kuhnke, Lives at Risk, pp. 89-98; Panzac, La Peste dans l'Empire Ottoman, pp. 480-3.

5. Kuhnke, Lives at Risk, p. 76.

6. Abd al-Rahmān Jabarti, Napoleon in Egypt: Al-Jabartī's Chronicle of the French Occupation, 1798, p. 71.

7. Jabarti, Napoleon in Egypt, p. 14.

8. Hamdan, Tercüme-i İthaf, fol. 39B.

9. Hamdan, Tercüme-i İthaf, fol. 46A.

10. Hamdan, Tercüme-i Ithaf, fols 56B-57A, 64B-65A.

11. Maclean, Results of an Investigation, p. 457.

12. Maclean, Results of an Investigation, pp. 47-8.

13. DeKay, Sketches of Turkey in 1831 and 1832, p. 162.

14. Stanford J. Shaw, Between Old and New: The Ottoman Empire under Sultan Selim III, 1789-1807, pp. 92, 100, 103-4, 375.

15. Uludağ, 'Son Kapitülasyonlardan biri Karantina', p. 448.

16. Lago, Risale-i Karantina, fols 1A, 2B, 21B-22A.

17. Hamdan, Tercüme-i Ithaf, fol. 62A.

18. Hamdan, Tercüme-i İthaf, fol. 62B.

19. Hamdan, Tercüme-i Itthaf, fols 62B, 63A-B.

20. Hamdan, Tercüme-i İthaf, fols 63A-64A.

21. Lago also had a similar description of the quarantine and those people and goods who should be inspected by its officials. Lago, Risale-i Karantina, fols 2A-19A.

22. Panzac, La Peste dans l'Empire Ottoman, pp. 515-18; Kuhnke, Lives at Risk, pp. 92-9.

23. DeKay, Sketches of Turkey in 1831 and 1832, pp. 336-7.

24. Panzac, La Peste dans l'Empire Ottoman, p. 580.

25. Maclean, Results of an Investigation, pp. 427-8.

26. Hamdan, Tercüme-i İthaf, fol. 59A.

27. Hamdan, Tercüme-i İthaf, fol. 43B.

28. Hamdan, Tercüme-i İthaf, fols 43B-46A, 59A.

29. Panzac, La Peste dans l'Empire Ottoman, pp. 583-5.

30. Hamdan, Tercüme-i İthaf, fol. 39B.

31. Hamdan, Tercüme-i İthaf, fol. 44B.

32. Hamdan, Tercüme-i İthaf, fol. 45A.

33. Hamdan, Tercüme-i İthaf, fols 45A, 65B.

34. İnalcik, 'The Tanzimat and its social effects', p. 12.

35. Panzac, La Peste dans l'Empire Ottoman, pp. 583-5.

36. Hamdan Khodja, Le Miroir: Aperçu Historique et Statistique sur la Régence d'Alger, p. 174.

37. Hamdan Khodja, Le Miroir, p. 87.

38. Panzac, La Peste dans l'Empire Ottoman, pp. 493-514; Abdeljelil Temimi, Le Beylik de Constantine et Hadj Ahmed Bey (1830-1837), pp. 7-10. 
39. Frank Edgar Bailey, British Policy and the Turkish Reform Movement: A Study in AngloTurkish Relations, 1826-1853, pp. 86-7, 93.

40. Urquhart, Turkey and its Resources: Its Municipal Organization and Free Trade; the State and Prospects of English Commerce in the East, the New Administration of Greece, its Revenue and National Possessions, pp. 143-4.

41. Hamdan, Tercüme-i İthaf, fols 64B-65A.

42. Irfan Habib, 'Colonization of the Indian economy, 1757-1900', pp. 23-30.

43. Hamdan, Tercüme-i İthaf, fols 34B, 36B.

44. Hamdan, Tercüme-i Itthaf, fol. 67A.

45. Rhoads Murphey, Ottoman Warfare, 1500-1700, pp. 13-14.

46. Berkes, Development of Secularism in Turkey, pp. 90-7.

47. Hamdan, Tercüme-i İthaf, fol. 67A.

48. Berkes, Development of Secularism in Turkey, p. 113.

49. Clot-Bey, the French expatriate who Mohammed Ali directed to found the first modern medical school in Egypt in 1827 came to a similar conclusion: 'In order to be lasting, useful institutions [like the medical school] should be national and independent of the cooperation of foreigners.' Kuhnke, Lives at Risk, p. 34.

50. Hamdan, Tercüme-i İthaf, fol. 65A.

51. Hamdan, Tercüme-i İthaf, fols 66B-67A.

52. Panzac, La Peste dans l'Empire Ottoman, pp. 481-2.

53. The French also made a similar protest to the Tunisian government in 1828 , on the eve of its invasion of Algeria. Husayn Bey, the Bey of Tunis, replied to de Lesseps, the Consul General of France to Tunis: 'Your request was to remove the quarantine from merchant ships coming from your Mediterranean ports. We have considered your request and the answer is that we ordered the ten days to protect the people. God Almighty gave us the duty to take care of their welfare and to protect them from contagious diseases. It came to us from many authoritative sources that plague, yellow fever and other diseases are spreading. Yellow fever is severe in Gibraltar and elsewhere. We know that merchant ships have contact with other ships at sea and in port so we ordered these ten days to protect the land and the people... We put this order on all types of ships coming to our country. Orders cannot be done for some and not for others. If we accept your request, others would demand it and enforcing the order would become very difficult. The result would be corruption coming to our country ... France with its ancient friendship with us, understands that we did not order the quarantine to hinder commerce. We made the order not knowing if it will work, but it might, so it's not possible for us not to do it ...' Gallagher, Medicine and Power in Tunisia, p. 106.

54. Kuhnke, Lives at Risk, pp. 2-15; Gallagher, Medicine and Power in Tunisia, p. 32.

55. Mead, Short Discourse, p. 13.

56. Lago, Risale-i Karantina, fols 7A, 12B-13B, 21B-22A.

57. Erwin Ackerknecht, 'Anticontagionism between 1821 and 1867', pp. 562-93.

58. Michel Foucault, Kliniğin Doğusu, pp. 7-18; Bruno Latour, The Pasteurization of France, pp. 3-12.

59. James C. Scott, Seeing like a State: How Certain Schemes to Improve the Human Condition Have Failed, pp. 1-8.

60. Baldwin, Contagion and the State in Europe, 1830-1930, pp. 24-5.

61. Patrick Russell, A Treatise of the Plague, p. 480.

62. Mead, Short Discourse, p. 15. 
63. Mead, Short Discourse, p. 24.

64. Mead, Short Discourse, pp. 18-19.

65. Howard, Account of the Principal Lazarettos in Europe, p. 34.

66. Howard, Account of the Principal Lazarettos in Europe, p. 25.

67. Patrick Russell, A Treatise of the Plague, p. 551.

68. Roy Porter, British Enlightenment, pp. 358-9.

69. Mead, Short Discourse, p. 15.

70. Patrick Russell, A Treatise of the Plague, p. 501.

71. Maclean, Results of an Investigation, p. 456.

72. Maclean, Results of an Investigation, p. 429.

73. Roy Porter, British Enlightenment, pp. 470-5.

74. Explainer, Distinct Notions of the Plague, p. 126.

75. Maclean, Results of an Investigation, pp. 2, 107.

76. Patrick Russell, A Treatise of the Plague, p. 501.

77. DeKay, Sketches of Turkey in 1831 and 1832, pp. 337-8.

78. DeKay, Sketches of Turkey in 1831 and 1832, p. 340.

79. DeKay, Sketches of Turkey in 1831 and 1832, p. 338.

80. DeKay, Sketches of Turkey in 1831 and 1832, p. 339.

81. Maclean, Results of an Investigation, pp. 425-6.

82. DeKay, Sketches of Turkey in 1831 and 1832, p. 131.

83. Maclean, Results of an Investigation, p. 425.

84. This inference is based on DeKay's detailed summary and translation of Behçed Efendi, who was part of the 1830-1 commission studying the effectiveness of quarantines for fighting cholera and plague, and Maclean's claim about the 'contagionist' Grand Vizier. DeKay, Sketches of Turkey in 1831 and 1832, p. 336; Maclean, Results of an Investigation, pp. 427-8.

85. DeKay, Sketches of Turkey in 1831 and 1832, p. 155.

86. DeKay, Sketches of Turkey in 1831 and 1832, p. 362.

87. DeKay, Sketches of Turkey in 1831 and 1832, p. 362.

88. DeKay, Sketches of Turkey in 1831 and 1832, p. 358.

89. DeKay, Sketches of Turkey in 1831 and 1832, p. 175.

90. Boccaccio, The Decameron, pp. 6-14.

91. DeKay, Sketches of Turkey in 1831 and 1832. p. 189.

92. DeKay, Sketches of Turkey in 1831 and 1832, pp. 130-1.

93. DeKay, Sketches of Turkey in 1831 and 1832, pp. 130-1; Maclean, Results of an Investigation, p. 425.

94. Howard, Account of the Principal Lazarettos in Europe, p. 40.

95. Howard, Account of the Principal Lazarettos in Europe, p. 25.

96. Howard, Account of the Principal Lazarettos in Europe, pp. 175-6.

97. Howard, Account of the Principal Lazarettos in Europe, pp. 175-6.

98. Howard, Account of the Principal Lazarettos in Europe, pp. 190-1.

99. Howard, Account of the Principal Lazarettos in Europe, p. 64.

100. Maclean, Results of an Investigation, p. 44.

101. DeKay, Sketches of Turkey in 1831 and 1832, p. 344.

102. DeKay, Sketches of Turkey in 1831 and 1832, p. 332.

103. Nadir Özbek, 'The Politics of Welfare: Philanthropy, Voluntarism and Legitimacy in the Ottoman Empire, 1876-1914', p. 36. 
104. Uludağ, 'Son Kapitülasyonlardan biri Karantina', pp. 445-6.

105. Hamdan, Tercüme-i İthaf, fol. 64B.

106. Lago, Risale-i Karantina, fol. 13B.

107. Panzac, La Peste dans l'Empire Ottoman, pp. 481-2.

108. Uludağ, 'Osmanlı Tıp Tarihinde Reaya Hastaneleri ve İmtiyazları', pp. 279-81.

109. Hamdan Khodja, Miroir, p. 138.

110. İnalcik, Ottoman Empire, p. 156. 